\title{
Przerzut guza nerki w drodze odpływu prawej komory operowany ze wskazań życiowych
}

\author{
Metastatic tumour in right ventricular outflow tract treated surgically \\ for life-saving indications
}

\author{
Andrzej Wojtarowicz, Mirosław Brykczyński \\ Klinika Kardiochirurgii Pomorskiego Uniwersytetu Medycznego w Szczecinie
}

\begin{abstract}
Streszczenie
U pacjentki z guzem prawej nerki w trakcie przygotowań do operacji stwierdzono w drodze odpływu prawej komory guz o niejasnej etiologii. Zmiana ta w istotnym stopniu zaburzała przepływ krwi, powodując przeciążenie prawej komory, niewydolność serca w III klasie według New York Heart Association i została uznana za czynnik ryzyka nagłego zgonu. Guz serca operowano w trybie pilnym; w badaniu histopatologicznym okazał się przerzutem raka nerki.
\end{abstract}

Słowa kluczowe: guz serca, niewydolność serca, rak nerki

Folia Cardiologica 2016; 11, 2: 157-159

\section{Wstęp}

Pierwotne guzy serca, zwłaszcza dotyczące prawej komory (RV, right ventricle), są bardzo rzadkie. Częściej spotyka się guzy przerzutowe lub naciekające serce przez ciągłość. $Z$ hemodynamicznego punktu widzenia guz - niezależnie od etiologii - może w istotnym stopniu zaburzać hemodynamikę i być potencjalnym źródłem materiału zatorowego. W tej sytuacji istnieją wskazania do pilnego leczenia operacyjnego guza serca ze wskazań życiowych.

\section{Opis przypadku}

U 53-letniej pacjentki rozpoznano guz nerki prawej z prawdopodobnym przerzutem do wątroby. W przeddzień planowanej operacji badający pacjentkę anestezjolog stwierdził szmer nad sercem i skierował ją na konsultację kardiologiczną. Chora zgłaszała narastające od kilku miesięcy upośledzenie wydolności wysiłkowej (do III klasy wg New York Heart Association [NYHA]). Występował głośny szmer skurczowy (4/6), najgłośniejszy nad podstawą serca. W badaniu echokardiograficznym stwierdzono ruchomy guz o wymiarach $30 \times 50 \mathrm{~mm}$, szeroko uszypułowany w drodze odpływu prawej komory (RVOT, right ventricular outflow tract), około 1,5 cm przed zastawką tętnicy płucnej, przemieszczający się w czasie skurczu w kierunku tej zastawki i istotnie upośledzający przepływ w RVOT (ryc. 1-3). Obraz guza zbliżony był do śluzaka. Stwierdzono takie cechy przeciążenia RV, jak elipsoidalny kształt komory lewej (LV, left ventricle), paradoksalny skurcz przegrody międzykomorowej oraz poszerzenie RV (ryc. 4). Gradient ciśnień w RVOT wynosił $50 \mathrm{~mm} \mathrm{Hg,}$ a gradient fali niedomykalności trójdzielnej $55 \mathrm{~mm} \mathrm{Hg}$. W prawym przedsionku (RA, right atrium) ani w żyle głównej dolnej żadnych zmian nie stwierdzono. W rozpoznaniu wzięto pod uwagą koincydencję pierwotnego guza w RVOT i przerzut z ogniska pierwotnego. Wobec nasilonych zaburzeń hemodynamicznych spowodowanych ograniczeniem przepływu krwi przez RVOT i dużego ryzyka zgonu w przypadku wystąpienia zatoru tętnicy płucnej podjęto decyzję o przeprowadzeniu operacji kardiochirurgicznej w trybie pilnym. Z powodu braku łączności opisanego guza ze zmianą w nerce odstąpiono od przeprowadzenia jednoczasowej operacji serca i nerki. 


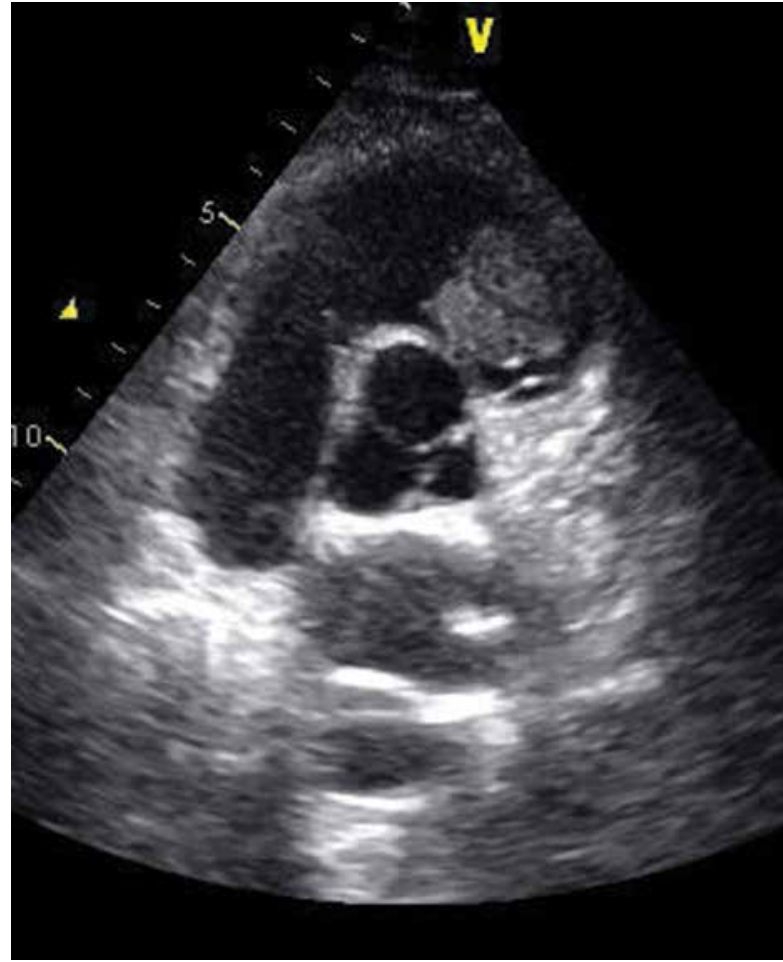

Rycina 1. Guz zajmujący prawie całą szerokość drogi odpływu prawej komory (2D)

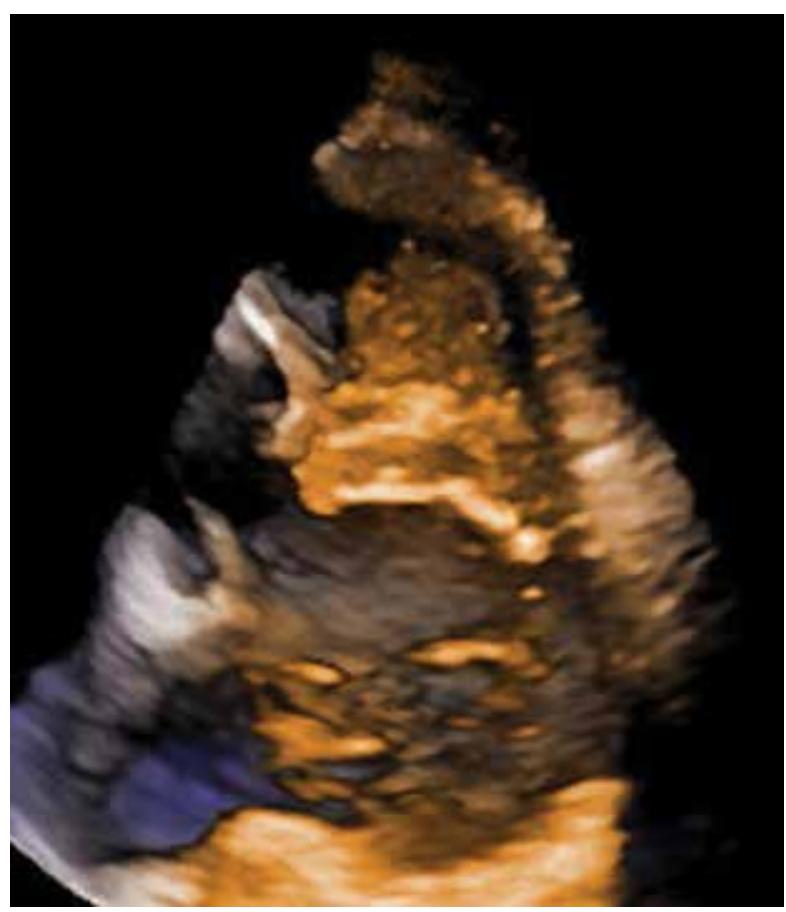

Rycina 2. Ten sam guz uwidoczniony w badaniu 3D

Operację przeprowadzono z użyciem krążenia pozaustrojowego, pod kontrolą echokardiografii przezprzełykowej (TEE, transesophagal echocardiography). Serce

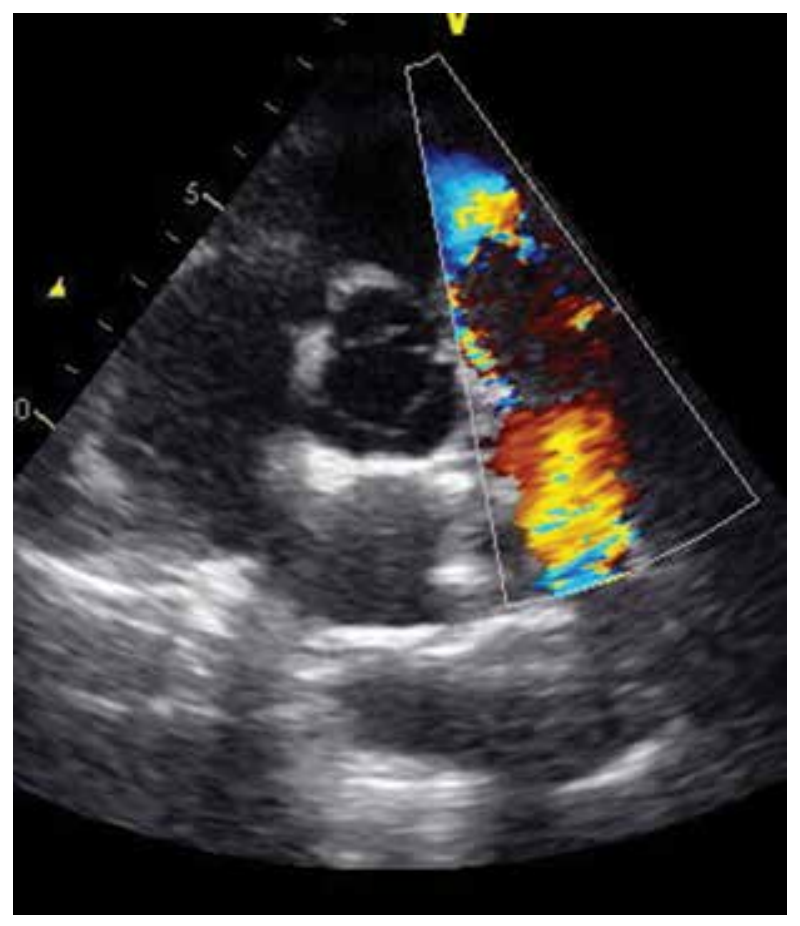

Rycina 3. Przepływ z prawej komory do tętnicy płucnej opływający guz (kolorowy dopler)

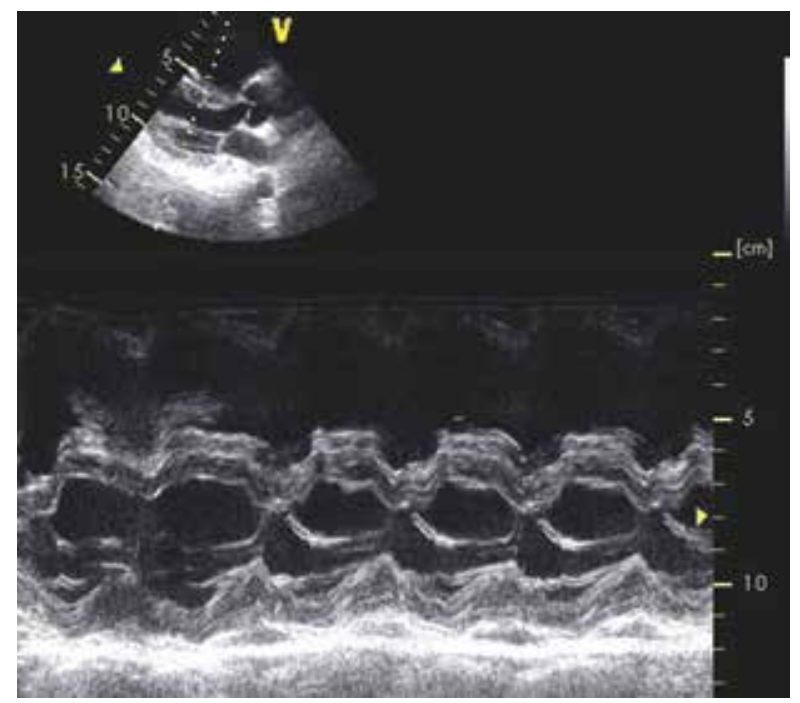

Rycina 4. Poszerzona prawa komora z paradoksalnym skurczem przegrody międzykomorowej (M-mode)

zatrzymano krystaliczną kardioplegią i otwarto RV poniżej zastawki płucnej. Stwierdzono uszypułowany na 15-milimetrowej stopce guz o wymiarach $25 \times 55 \mathrm{~mm}$. Podstawa guza była twardsza, mocno związana z podłożem, obwód tworzyły rozpadające się tkanki. Guz usunięto w całości i oczyszczono podstawę znajdującą się między przegrodą międzykomorowa a wolną ścianą RV. Przebieg pooperacyjny był bez powikłań. W kolejnych badaniach 
echokardiograficznych nie stwierdzano zaburzeń przepływu w RVOT. Obniżyło się też ciśnienie w RV. W badaniu histopatologicznym N 66236-8/13 stwierdzono przerzut raka jasnokomórkowego nerki. Po krótkiej rehabilitacji pooperacyjnej chora została skierowana do Kliniki Chirurgii Ogólnej i Transplantacyjnej Pomorskiego Uniwersytetu Medycznego w Szczecinie w celu dalszego leczenia. Przed operacją wszczepiono czasowy filtr do żyły głównej dolnej. Następnie bez powikłań usunięto nerkę wraz z węzłami chłonnymi. Leczenie interwencyjne zakończono usunięciem filtra z żyły głównej dolnej i skierowaniem do dalszego leczenia onkologicznego.

\section{Omówienie}

Nowotwór nerki jest jednym z najczęściej rozpoznawanych nowotworów. W Europie odnotowuje się 15,8 takich nowotworów na 100000 mężczyzn i 7,1 u kobiet. Śmiertelność z tego powodu wynosi 56\% u mężczyzn i 39\% u kobiet [1]. Nowotwór ten w początkowym stadium przebiega skąpoobjawowo, aż 25-30\% pacjentów ma przerzuty w chwi- li ustalenia rozpoznania pierwotnego [2]. Dodatkowo w 5-10\% przypadków guzów nerki można rozpoznać zmiany zakrzepowo-nowotworowe które przez żyłę nerkową wpuklają się do żyły głównej dolnej w kierunku do RA. Zmiany te mogą powodować zaburzenia przepływu w drodze napływu do RV z żyły głównej dolnej i z RA do RV. W nowotworach nerki guzy przerzutowe do serca bez łączności ze zmianą pierwotną przez żyłę główną zdarzają się sporadycznie $[3,4]$. Guzy serca (zarówno pierwotne, jak i przerzutowe) wyjątkowo rzadko lokalizują się w RVOT, a różnicowanie guzów o tej lokalizacji jest trudne [5, 6]. Duży guz w RVOT znacznie utrudnia napływ krwi do krążenia płucnego oraz może być przyczyną masywnej zatorowości płucnej, a więc jest czynnikiem ryzyka nagłej dekompensacji krążeniowej lub nagłego zgonu. W tej sytuacji usunięcie guza w trybie pilnym, przed operacją ewentualnego ogniska pierwotnego jest zdecydowanie uzasadnione.

\section{Konflikt interesów}

Autorzy deklarują brak konfliktu interesów.

\section{Abstract}

Patient with a right-sided kidney tumour in whom during pre-surgery examination a cryptogenic tumour was revealed in a right ventricular outflow tract. The tumour significantly impeded blood flow, causing right ventricle overload, heart failure in class III of New York Heart Association classification and was recognized as a risk factor of sudden cardiac death. The tumour in the heart was operated in an emergency setting. It transpired to be a metastasis of the kidney cancer in histopathological examination.

Key words: cardiac tumours, heart failure, renal cell carcinoma

Folia Cardiologica 2016; 11, 2: 157-159

\section{Piśmiennictwo}

1. Carroll J.C., Quinn C.C., Weitzel J., Sant G.R. Metastatic renal cell carcinoma to the right cardiac ventricle without contiguous vena caval involvement. J. Urol. 1994; 151: 133-134.

2. Atik F.A., Navia J.L., Krishnamurthi V. i wsp. Solitary massive right ventricular metastasis of renal cell carcinoma without inferior vena cava or right atrium involvement. J. Card. Surg. 2006; 21: 304-306.

3. Gupta K., Miller J.D, Li J.Z. i wsp. Epidemiologic and socioeconomic burden of metastatic renal cell carcinoma (mRCC): a literature review. Cancer Treat. Rev. 2008; 34: 193-205.
4. Ljungberg B., Campbell S.C., Choi H.Y. i wsp. The epidemiology of renal cell carcinoma. Eur. Urol. 2011; 60: 615-621.

5. Sayin O.A., Ugurlucan M., Cinar T. i wsp. Right ventricular myxoma causing right ventricular outflow tract obstruction. J. Card. Surg. 2007; 22: $227-229$.

6. Gopal A.S., Stathopoulos J.A., Arora N. i wsp. Differential diagnosis of intracavitary tumors obstructing the right ventricular outflow tract. J. Am. Soc. Echocardiogr. 2001; 14: 937-940. 